\title{
Effects of clomiphene citrate on ovarian function in hypophysectomized rats
}

\author{
Y. S. Moon, A. J. Duleba, Y. W. Yun and B. Ho Yuen \\ Department of Obstetrics and Gynaecology, University of British Columbia, Vancouver, \\ British Columbia, Canada V6H 3 V5
}

\begin{abstract}
Summary. On Days 28-30 of age, hypophysectomized rats were treated with oestradiol$17 \beta(0.1 \mathrm{mg} /$ day $)$ and/or clomiphene citrate $(0.1 \mathrm{mg} /$ day $)$. Subsequent treatment with PMSG (10 i.u., on Day 31) and hCG (10 i.u., on Day 33) wasidentical for all animals. Rats were killed on Day 34. Treatment with oestradiol-17 $\beta$ alone resulted in ovulations of $45 \cdot 1 \pm 5 \cdot 5$ oocytes/rat (mean \pm s.e.m.). There were no ovulations among animals treated with clomiphene citrate alone but treatment with oestradiol-17 $\beta$ and clomiphene citrate resulted in a significant $(P<0.05)$ reduction $(23.1 \pm 7.6$ oocytes/rat $)$ in ovulatory response. Similarly, ovarian weights and serum progesterone concentrations were highest in the oestradiol-17 $\beta$-treated rats, intermediate in those given oestradiol plus clomiphene citrate and the lowest in rats receiving clomiphene citrate alone. We suggest that clomiphene citrate exerts direct ovarian antiovulatory and oestrogen-antagonist actions.
\end{abstract}

Keywords: clomiphene citrate; ovulation; rat; hypophysectomy

\section{Introduction}

Clomiphene citrate is a triphenylethylene derivative commonly used in ovulation induction in women (Huppert, 1979; Adashi, 1986). It has been shown to interact with oestrogen-dependent/-responsive tissues including the hypothalamic-pituitary unit, ovary, endometrium and vaginal mucosa. Oestrogen-agonist and -antagonist activities of clomiphene citrate have been reported, depending on the species, the target tissue and the length of exposure (Clark \& Markaverich, 1982).

Induction of ovulation by clomiphene citrate is thought to be due to its effects at the hypothalamopituitary level by removal of negative feedback of endogenous oestrogens and the consequent increased release of gonadotrophins (Roy et al., 1963; Igarashi et al., 1967; Wu, 1977). It has been proposed that, in addition to the hypothalamo-pituitary effects, direct action(s) of clomiphene citrate at the ovarian level may also affect ovulation (Adashi, 1984).

The effects of clomiphene citrate on the ovary, however, remain poorly understood. Clomiphene citrate can exert inhibitory and stimulatory actions on a variety of ovarian functions, including alteration of steroidogenesis (Laufer et al., 1982; Welsh et al., 1984; Westfahl \& Resko, 1983; Sgarlata et al., 1984; Zhuang et al., 1982) and promotion of degeneration of oocytes (Laufer et al., 1983; Yoshimura et al., 1985; Schmidt et al., 1985).

The present study was designed to determine whether, and if so, how, ovarian functions are affected by direct action(s) of clomiphene citrate. The effects of clomiphene citrate on (i) the number of ovulated oocytes, (ii) ovarian weights, and (iii) serum steroid concentrations in hypophysectomized immature rats were therefore investigated.

\section{Materials and Methods}

Immature (24-day old) Sprague-Dawley rats were obtained from Charles River (St Constant, Quebec, Canada) after hypophysectomy at 21 days of age. The animals were housed in a temperature-controlled environment $\left(21^{\circ} \mathrm{C}\right)$ with 
lights on at $07: 00 \mathrm{~h}$ and off at 19:00 h. Daily subcutaneous injections with oestradiol- $17 \beta(0 \cdot 1 \mathrm{mg} / 0 \cdot 4 \mathrm{ml} \mathrm{sesame} \mathrm{oil)}$ and/or clomiphene citrate $(0.1 \mathrm{mg} / 0.4 \mathrm{ml}$ sesame oil) were given at 09:00 $\mathrm{h}$ for 3 days starting at the age of $28 \mathrm{days}$. The rats received oestradiol-17 $\beta$ alone (Group 1, $N=8$ ), clomiphene citrate alone (Group 2, $N=7$ ) or oestradiol$17 \beta+$ clomiphene citrate (Group 3, $\mathrm{N}=7$ ). On the 31 st day of age, all rats received a single subcutaneous dose of PMSG (10 i.u./0.4 ml 0.154 M-NaCl), followed on the $33 \mathrm{rd}$ day of age by a single dose of hCG $(10 \mathrm{i} . \mathrm{u} . / 0.4 \mathrm{ml} 0.154 \mathrm{M}-$ $\mathrm{NaCl}$ ). All animals were killed on the morning of Day 34, approximately $24-26 \mathrm{~h}$ after the dose of hCG.

Progesterone, oestradiol-17 $\beta$, clomiphene citrate, and testosterone were purchased from Sigma Chemical Company (St Louis, MO, USA). PMSG and hCG were purchased from Ayerst, McKenna and Harrison Incorporated (Vancouver, British Columbia, Canada). [1,2,6,7,16,17- $\left.{ }^{3} \mathrm{H}\right]$ Progesterone (sp. act. $112 \mathrm{Ci} / \mathrm{mmol}$ ), [2,4,6,7,16,17${ }^{3} \mathrm{H}$ ]oestradiol-17 $\beta$ (sp. act. $140 \mathrm{Ci} / \mathrm{mmol}$ ) and $\left[2,6,7-{ }^{3} \mathrm{H}\right]$ testosterone (sp. act. $80 \mathrm{Ci} / \mathrm{mmol}$ ) were obtained from Amersham Company (Arlington Heights, IL, USA). Solvents were of analytical grade and were used without further purification, except for ethanol, which was redistilled.

Animals were killed by cervical dislocation. Trunk blood was collected and serum was separated. Ovaries were dissected and weighed as a pair. Ovulation was determined by counting oocytes flushed out from oviducts as described previously (Yun et al., 1987). Oocytes were counted under a dissecting microscope ( $\times 40$ magnification).

The concentrations of progesterone, oestradiol-17 $\beta$ and androgens in serum were measured by radioimmunoassay after extraction of serum twice with 5 volumes of diethyl ether. Specific antisera were kindly donated by Dr David T. Armstrong from the University of Western Ontario (London, Ontario). The cross-reactivity of the progesterone antiserum was progesterone, $100 \% ; 5 \beta$-pregnane-3,20-dione, $35 \cdot 5 \% ; 5 \alpha$-pregnane- 3,20 -dione, $15 \cdot 7 \% ; 3 \alpha$-hydroxy-5 3 pregnan-20-one, $2.0 \% ; 20 \beta$-hydroxy-4-pregnen-3-one, $1.3 \% ; 17$-hydroxyprogesterone, $1 \cdot 2 \%$; other major steroids known to be secreted by the follicle, less than $0 \cdot 2 \%$. The cross-reactivity of the oestradiol-17 $\beta$ antiserum was: oestradiol$17 \beta, 100 \%$; oestrone, $2.9 \%$; oestriol, $0.5 \%$; other major steroids known to be secreted by the follicle, $<0 \cdot 2 \%$. The cross-reactivity of the testosterone antiserum was: testosterone, $100 \% ; 5 \alpha$-dihydrotestosterone, $75 \% ; 5 \alpha$-androstane-

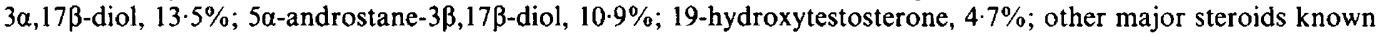
to be secreted by the follicle, $<1 \%$. Intra-assay and inter-assay coefficients of variation were less than $10 \%$ and $15 \%$, respectively. The cross-reactivity with other androgens was substantial and therefore steroids measured using this antiserum are referred to as androgens rather than testosterone.

Experimental data were evaluated statistically by analysis of variance followed by Scheffés F-test. Comparisons at $P<0.05$ were considered significant.

\section{Results}

Ovulation occurred in all 8 rats in Group 1, none in Group 2 and 5 of 7 rats in Group 3 (Fig. 1a).

The average weight of a pair of ovaries for rats in Group 1 was greater than the corresponding value for Group 2 rats and ovarian weights in Group 3 were intermediate (Fig. Ib).

Significant effects were observed for only progesterone with its highest levels observed in Group 1 and the lowest levels in Group 2 (Fig. 2).
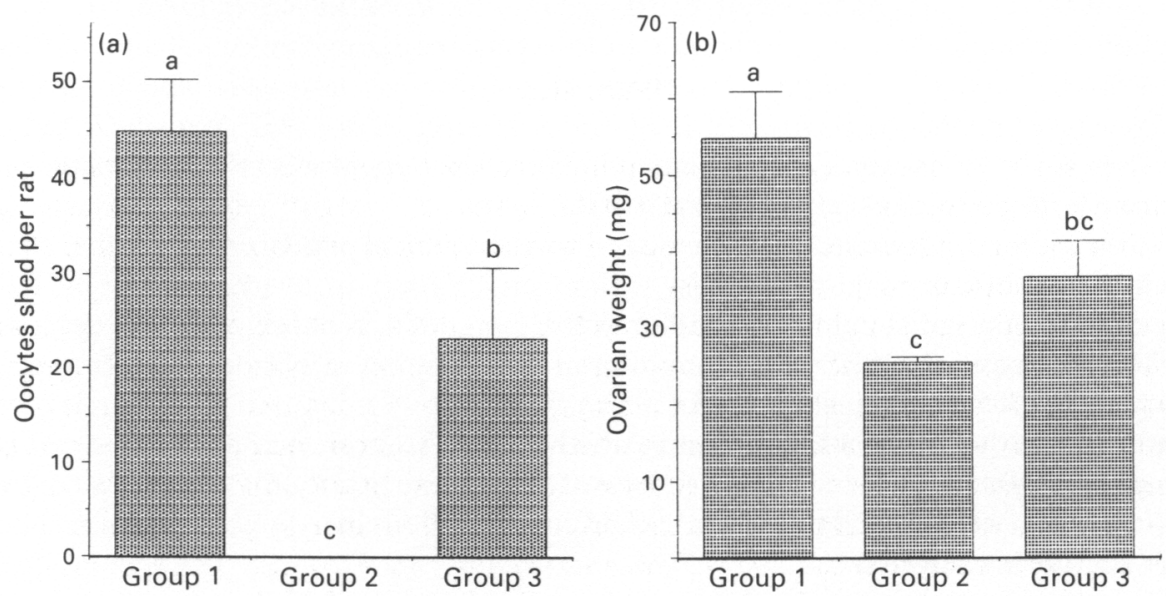

Fig. 1. Effect of oestradiol-17ß $(0 \cdot 1 \mathrm{mg} /$ day $)$ and/or clomiphene citrate $(0 \cdot 1 \mathrm{mg} /$ day $)$ administered on Days 28-30 of age on (a) total number of released oocytes and (b) ovarian weight. Group 1, 8 rats oestradiol-17 $\beta$ alone; Group 2, 7 rats, clomiphene citrate alone; Group 3, 7 rats, oestradiol- $17 \beta+$ clomiphene citrate. Values are means \pm s.e.m. The means with no superscripts in common are significantly different $(P<0.05)$. 


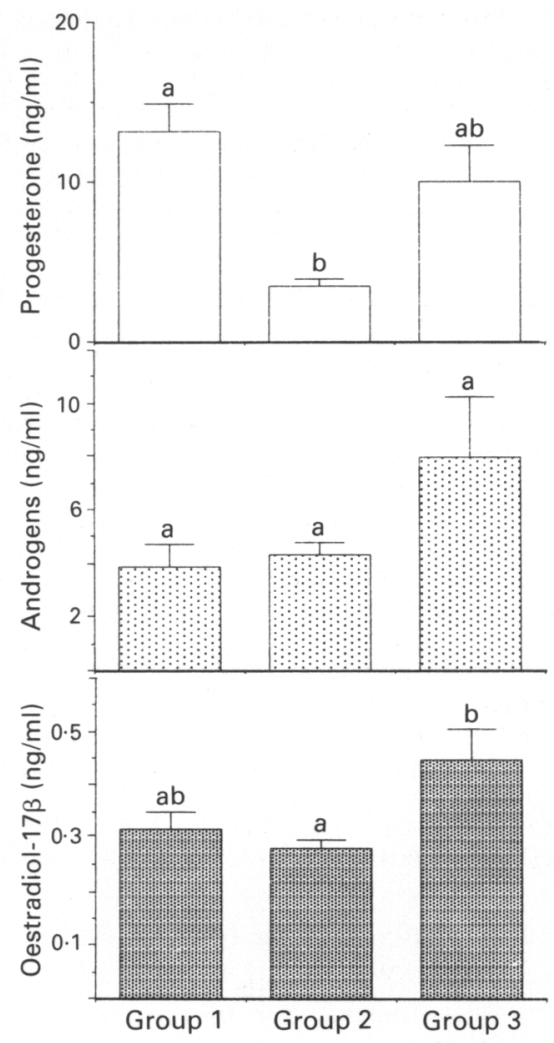

Fig. 2. Effect of oestradiol- $17 \beta(0.1 \mathrm{mg} /$ day $)$ and/or clomiphene citrate $(0.1 \mathrm{mg} /$ day $)$ administered on Days 28-30 of age on serum concentrations of progesterone, androgens and oestradiol17ß. Group 1, 8 rats, oestradiol-17 $\beta$ alone; Group 2, 7 rats, clomiphene citrate alone; Group 3, 7 rats, oestradiol- $17 \beta+$ clomiphene citrate. Values are means \pm s.e.m. The means with no superscripts in common are significantly different $(P<0.05)$.

\section{Discussion}

In the present study we have induced ovulation in immature hypophysectomized rats by a sequential treatment with oestradiol-17 , PMSG and hCG. In such animals, the effects of sex steroids and their agonists and/or antagonists are presumed to be due to direct ovarian effects rather than those exerted via the hypothalamo-pituitary axis.

The administration of clomiphene citrate resulted in inhibition of the ovulatory response with an associated decrease of ovarian weight and serum progesterone concentrations. It appears that the early phase of follicular development ensuring gonadotrophin-induced ovulation is oestrogendependent, and that administration of clomiphene citrate has detrimental effect(s) on this process. Oestrogens have been shown to stimulate ovarian function directly and to promote follicular growth (Pencharz, 1940; Williams, 1940; Richards et al., 1976) and to prevent follicular atresia (Reiter et al., 1972; Louvet et al., 1975). The antiovulatory and ovarian weight-limiting actions of clomiphene citrate observed in the present study may therefore be viewed as oestrogenantagonistic. Indeed, while clomiphene citrate has been described as a mixed oestrogen agonist/ antagonist, most of its documented actions are of an oestrogen-antagonistic nature (Adashi, 1984). It is believed that clomiphene citrate binds to oestrogen receptors and translocates these receptors to the nucleus. Clomiphene citrate-oestrogen receptor complexes appear to remain in the nucleus 
for a prolonged period of time with a resultant long-term depletion of the cytoplasmic oestrogen receptor pool (Sutherland \& Murphy, 1982; Jordan, 1984; Clark et al., 1985). Consequently, it is postulated that oestrogen-agonistic effects of clomiphene citrate are observed within the first day of its administration, while oestrogen-antagonistic effects are apparent only later.

The results of the present study, in which clomiphene citrate was administered over 3 days and its effects were observed even later, seem representative for the proposed delayed antioestrogenic action.

Previous studies with women and monkeys have also indicated that, while clomiphene citrate induced ovulation via the hypothalamic-pituitary axis, it also exerted inhibitory effects on ovarian follicular maturation and steroidogenesis (Marut \& Hodgen, 1982; Dlugi et al., 1985). Those observations, however, were carried out in the presence of an intact hypothalamus and pituitary and consequently any interferences regarding direct ovarian effects of clomiphene citrate were hypothetical.

Our observation of decreased serum progesterone concentrations in clomiphene citrate-treated animals is probably a secondary effect of a decreased number of ovulations and thus decreased number/mass of corpus luteum tissue. However, an additional direct inhibitory effect of clomiphene citrate on progesterone production may also be contributory. Such an effect has been observed previously in rat (Welsh et al., 1984) and human (Ho Yuen et al., 1988) granulosa cells.

In the present experiment we did not include animals treated with PMSG and hCG without clomiphene citrate and/or oestradiol. Our experience indicated that such animals ovulated erratically or not at all. Consequently, the most meaningful effects of clomiphene citrate observed in the present study represent its interactions with oestradiol-17 $\beta$.

This research was supported by grants from the Medical Research Council of Canada and the B.C. Health Care Research Foundation. We thank Dr David T. Armstrong, University of Western Ontario, London, Ontario, for the generous gift of antisera to progesterone, androgens and oestradiol-17ß; and Mrs Natalie M. Duleba and Mr Frank H. Yu for their skilful assistance.

\section{References}

Adashi, E.Y. (1984) Clomiphene citrate: mechanism(s) and site(s) of action--a hypothesis revisited. Fert. Steril. 42, 331-344.

Adashi, E.Y. (1986) Clomiphene citrate-initiated ovulation: a clinical update. Sem. Reprod. Endocrinol. 4, 255-276.

Clark, J.H. \& Markaverich, B.M. (1982) The agonisticantagonistic properties of clomiphene citrate: a review. Pharmac. Ther. 15, 467-519.

Clark, J.H., Winneker, R.C. \& Markaverich, B.M. (1985) Estrogen and antiestrogen binding sites: relation to the estrogen receptor and biological response. In Biochemical Actions of Hormones, Vol. XII, pp. 353-383. Ed. G. Litwack. Academic Press, Orlando.

Dlugi, A.M., Laufer, N., Botero-Ruiz, W., DeCherney, A.H., Lake Polan, M., Haseltine, F.P., Mezer, H.C. \& Behrman, H.R. (1985) Altered follicular development in clomiphene citrate versus human menopausal gonadotropin-stimulated cycles for in vitro fertilization. Fert. Steril. 43, 40-47.

Ho Yuen, B., Mari, N., Duleba, A.J. \& Moon, Y.S. (1988) Direct effects of clomiphene citrate on the steroidogenic capabilities of human granulosa cells. Fert. Steril. 49, 626-631.

Huppert, L.C. (1979) Induction of ovulation with clomiphene citrate. Fert. Steril. 31, 1-9.
Igarashi, M., Ibuki, Y., Kubo, M., Kamioka, J., Yokota, N., Ebara, Y. \& Matsumoto, S. (1967) Mode and site of action of clomiphene. Am. J. Obstet. Gynecol. 97 , $120-123$.

Jordan, C. (1984) Biochemical pharmacology of antiestrogen action. Pharmacol. Reviews 36, 245-276.

Laufer, N., Reich, R., Braw, R., Shenker, J.G. \& Tsafriri, A. (1982) Effects of clomiphene citrate on preovulatory rat follicles in culture. Biol. Reprod. 27, 463-471.

Laufer, N., Pratt, B.M., DeCherney, A.H., Naftolin, F., Merino, M. \& Markert, C.L. (1983) The in vivo and in vitro effects of clomiphene citrate on ovulation, fertilization and development of cultured mouse oocytes. Am. J. Obstet. Gynecol. 147, 633-639.

Louvet, J-P., Harman, S.M. \& Ross, G.T. (1975) Effects of human chorionic gonadotropin, human interstitial cell-stimulating hormone and human follicle-stimulating hormone on ovarian weights in estrogen-primed hypophysectomized immature female rats. Endocrinology 96, 1179-1186.

Marut, E.L. \& Hodgen, G.D. (1982) Antiestrogenic action of high-dose clomiphene in primates: pituitary augmentation but with ovarian attenuation. Fert. Steril. 38, 100-104.

Pencharz, R.L. (1940) Effect of estrogens and androgens alone and in combination with chorionic gonadotro- 
pin on the ovary of the hypophysectomized rat. Science, NY 91, 554-555.

Reiter, E.O., Goldenberg, R.L., Vaitukaitis, J.L. \& Ross, G.T. (1972) Evidence for a role of estrogen in the ovarian augmentation reaction. Endocrinology 91 , 1518-1522.

Richards, J.S., Ireland, J.J., Rao, M.C., Bernath, G.A., Midgley, A.R. \& Reichert, L.E. (1976) Ovarian follicular development in the rat: hormone receptor regulation by estradiol, follicle stimulating hormone and luteinizing hormone. Endocrinology 99, 1562-1570.

Roy, S., Greenblatt, R.B., Mahesh, V.B. \& Jungck, E.C. (1963) Clomiphene citrate: Further observation on its use in induction of ovulation in the human and on its mode of action. Fert. Steril. 14, 575-595.

Schmidt, G.E., Sites, C., Mansour, R., Friedman, C.I. \& Kim, M.H. (1985) Embryo toxicity of clomiphene citrate on mouse embryos fertilized in vitro and in vivo. Am. J. Obstet. Gynecol. 153, 679-684.

Sgarlata, C.S., Mikhail, G. \& Hertelendy, F. (1984) Clomiphene and tamoxifen inhibit progesterone synthesis in granulosa cells: comparison with estradiol. Endocrinology 114, 2032-2038.

Sutherland, R.L. \& Murphy, L.C. (1982) Mechanism of oestrogen antagonism by nonsteroidal antioestrogens. Molec. cell. Endocrinol. 25, 5-23.
Welsh, T.H., Jia, X-C., Jones, P.B.C., Zhuang, L-Z. \& Hsueh, A.J.W. (1984) Disparate effects of triphenylethylene antiestrogens on estrogen and progestin biosynthesis by cultured rat granulosa cells. Endocrinology 115, 1275-1282.

Westfahl, P.K. \& Resko, J.A. (1983) Effects of clomiphene on luteal function in the nonpregnant cynomolgus macaque. Biol. Reprod. 29, 963-969.

Williams, P.C. (1940) Effect of stilboestrol on the ovaries of hypophysectomized rats. Nature, Lond. 145, 388-389.

Wu, C.H. (1977) Plasma hormones in clomiphene citrate therapy. Obstet. Gynecol. 49, 443-448.

Yoshimura, Y., Kitai, H., Santulli, R., Wright, K. \& Wallach, E.E. (1985) Direct ovarian effect of clomiphene citrate in the rabbit. Fert. Steril. 43, 471-476.

Yun, Y.W., Ho Yuen, B. \& Moon, Y.S. (1987) Effects of superovulatory doses of pregnant mare serum gonadotropin on oocyte quality and ovulatory and steroid hormone responses in rats. Gamete Res. 16, 109-120.

Zhuang, L-Z., Adashi, E.Y. \& Hsueh, A.J.W. (1982) Direct enhancement of gonadotropin-stimulated ovarian estrogen biosynthesis by estrogen and clomiphene citrate. Endocrinology 110, 2219-2221.

Received 19 January 1989 